\title{
ДИНАМИКА ЭТНОДЕМОГРАФИЧЕСКОЙ СИТУАЦИИ В МЕДЖУДСКОМ УЩЕЛЬЕ ЮЖНОЙ ОСЕТИИ (1886-2015 гг.)
}

\begin{abstract}
В работе исследуется динамика демографической ситуащии и этнического состава населения в Меджудском ущелье Южной Осетии с 1886 по 2015 г2. Меджудское ущелье на протяжении всего рассматриваемого периода имело периферийное экономико-географическое положение. В советское время ущелье не имело непосредственного транспортного сообщения с другими частями Южной Осетии и в экономическом плане было ориентировано преимущественно на Горийский район Грузии, что сильно осложнило гуманитарное положение в микрорегионе в изменивиихся после распада СССР политико-географических реалиях. Вышеперечисленные причины определили неуклонную депопуляцию населения Меджудского ущзелья начиная с 1940-х годов. Сокращение числа жителей особенно усилилось с начала 1990-х годов.
\end{abstract}

Ключевые слова: Меджудское ущзелье, Южная Осетия, этническая демография Кавказа, миграции на Южном Кавказе, осетины, мтиуль

Меджудское ущелье (по-осетински Медзыдагом) - физико-географический и историко-этнографический микрорегион, расположенный в восточной части Цхинвальского района Южной Осетии. Меджудское ущелье представляет собой горную часть долины реки Меджуда вместе с долинами всех ее горных притоков. На западе Меджудское ущелье граничит с Адзульским ущельем, на севере - с ущельем Малой Лиахвы, на северо-востоке - с находящимся на территории Ленингорского района Чуртинским ущельем, на востоке - с Лехурским ущельем (также в пределах Ленингорского района), на юге - с Картлийской равниной. Последняя граница является не только физико-географической, но и политической. Самое нижнее село Меджудского ущелья Гром, южнее которого, при выходе Меджуды на равнину, проходит грузино-югоосетинская государственная граница. С грузинской стороны границы расположено село Меджврисхеви Горийского муниципалитета края Шида-Картли, которое, несмотря на свое название ${ }^{1}$, расположено за пределами ущелья, уже при выходе из него. Пограничные села Гром и Меджврисхеви непосредственно примыкают друг к другу.

В советский период Меджудское ущелье, не имевшее непосредственного транспортного сообщения с другими частями Южной Осетии, экономически было свя-

Багапш Нури Валериевич - кандидат географических наук, доцент кафедры географии Абхазского государственного университета, научный сотрудник отдела этнологии Абхазского института гуманитарных исследований им. Д.И. Гулиа (Абхазия, Сухум, ул. Аидгылара, 44). Эл. почта: nbagapsh@gmail.com. Bagapsh, Nuri V. - Abkhaz State University, Abkhaz Institute for Humanitarian Studies (Sukhum, Aidgylara street, 44). E-mail: nbagapsh@gmail.com

${ }^{1}$ Меджврисхеви в переводе с грузинского означает «Меджудское ущелье», «Меджудская теснина». 
зано в первую очередь с находящимися ниже по течению реки равнинными грузинскими селами Горийского района и самим городом Гори. Подобная транспортная полуизоляция от экономико-географического центра Южной Осетии была характерна и для соседних Лехурского и Ксанского ущелий, что объясняется влиянием орографических факторов, определявших экономическую нецелесообразность прокладки транспортных артерий через горные хребты. Отсутствие непосредственного (минуя территорию Грузии) качественного транспортного сообщения со столицей Южной Осетии в изменившихся после распада СССР политико-географических реалиях сильно осложнило гуманитарную ситуацию в Меджудском и Лехурском ущельях, которые после завершения активной фазы грузино-югоосетинского конфликта в 1992 г. оказались в квазианклавном положении и экономической зависимости от соседних грузинских районов, что негативно отражалось на жизни местного населения вплоть до 2008 г. После августовской войны благодаря финансовой помощи РФ началось строительство современной автомагистрали Цхинвал Ленингор, проходящей по территории Меджудского ущелья. Трасса была сдана в эксплуатацию в 2014 г., превратив ущелье в транзитный регион и связав его как со столицей страны, так и с Ленингорским районом.

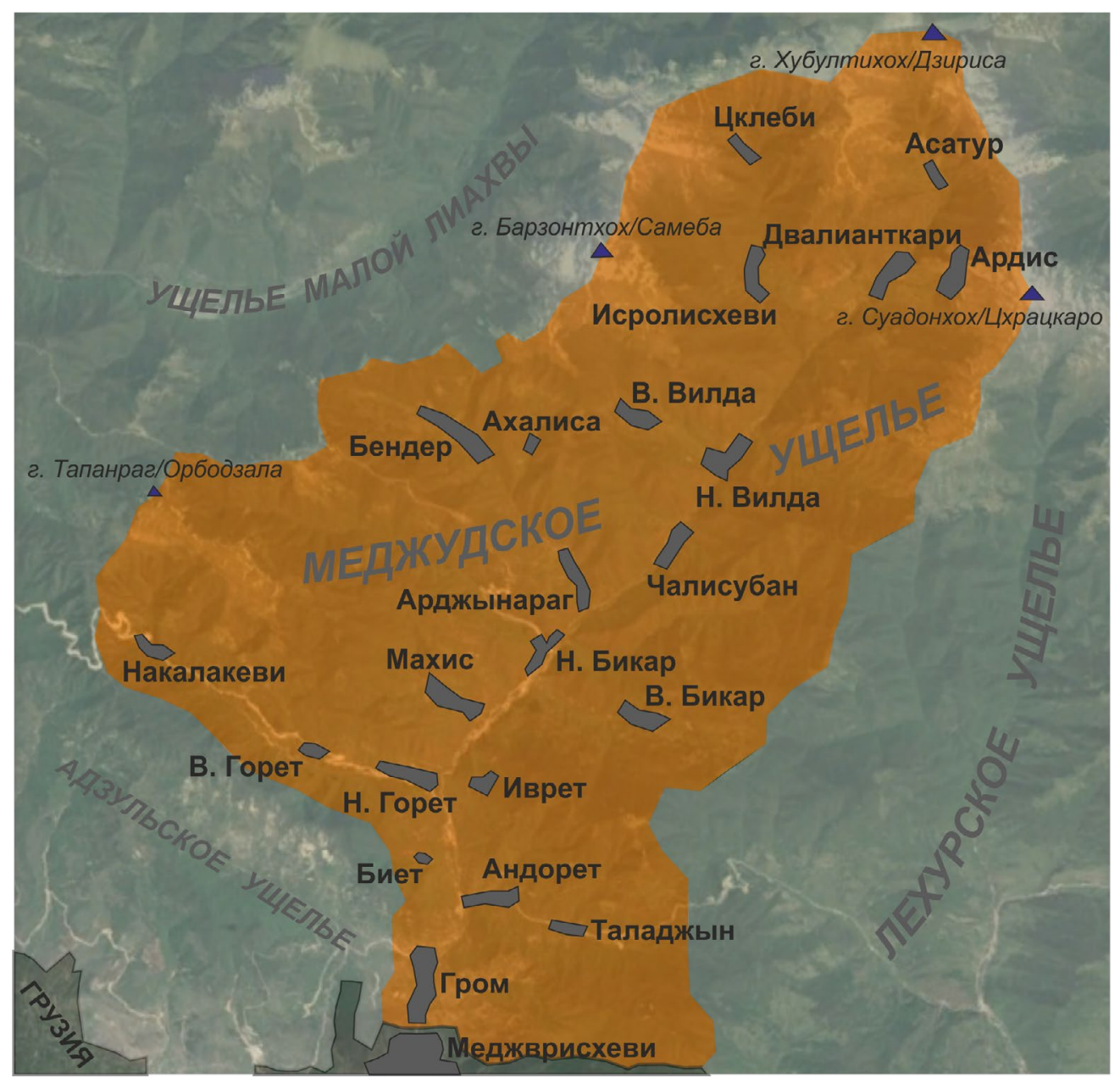

Рис. 1. Картосхема Меджудского ущелья. 
В дореволюционное время Меджудское ущелье находилось в границах Тифлисской губернии Российской империи: нижняя и средняя его части входили в состав Меджврисхевского участка Горийского уезда, верхняя - в состав Ксанского участка Душетского уезда (Кавказский 1996: 103, 108, 109). В 1920-е годы ущелье было административно разделено между Андоретской и Лехурской волостями (с середины 1920-х годов - между одноименными районами) Юго-Осетинской Автономной Области (Итоги 1925: 163, 167). С 1930 г. и вплоть до настоящего времени Меджудское ущелье входит в состав Цхинвальского района Южной Осетии (Административно-территориальное 1930: 183-196).

В настоящей работе рассматривается динамика этнодемографической ситуации в Меджудском ущелье по данным общегосударственных и региональных переписей населения, начиная с посемейной переписи 1886 г. и заканчивая Всеобщей переписью населения Республики Южная Осетия 2015 г. В промежутке между ними были проведены следующие советские переписи, данные которых для территории Меджудского ущелья имеются у нас в наличии: Всегрузинская сельскохозяйственная перепись 1923 г., Всесоюзные переписи населения 1926, 1959 и 1989 гг.

Одни из первых детальных сведений об этническом составе населения Меджудского ущелья представлены в итогах посемейной переписи, проведенной в Закавказье в 1886 г. По данным переписи, общая численность жителей ущелья составляла 3913 чел., из которых 1411 проживали в Ардисском сельском обществе Ксанского участка Душетского уезда (верхняя часть ущелья), а остальные 2502 - в Андоретском (без села Китриули), Бикарском, Кливанском (село Накалакеви), Лекаанском (без села Ципор) и Меджврисхевском (село Гром) сельских обществах Меджврисхевского участка Горийского уезда.

Таблица 1

\section{Этнический состав населенных пунктов Меджудского ущелья, 1886 г. (Свод 1893) ${ }^{1}$}

\begin{tabular}{|c|c|c|c|}
\hline & всего жителей & осетины & грузины \\
\hline Меджудское ущелье, в т.ч. & 3913 & 3528 & 385 \\
\hline Ардисское с/о, в т.ч. & 1411 & 1086 & 325 \\
\hline Ардиси & 124 & 124 & - \\
\hline Ашатури & 195 & 195 & - \\
\hline Берзаткари & 48 & 48 & - \\
\hline Вильда & 286 & 189 & 97 \\
\hline Исролисхеви & 227 & - & 227 \\
\hline Олопта & 143 & 143 & - \\
\hline
\end{tabular}

1 Здесь и в последующих таблицах названия населенных пунктов приводятся, как в источнике. Для верного соотнесения названий одних и тех же населенных пунктов в разных таблицах следует иметь в виду, что русскому «Верхний» соответствует грузинское «Земо», «Нижний» «Квемо», «Большой» - «Диди», «Малый» - «Патара». 
Таблица 1 (продолжение)

\begin{tabular}{|c|c|c|c|}
\hline & всего жителей & осетины & грузины \\
\hline тба & 251 & 251 & - \\
\hline Цольдиси & 1 & - & 1 \\
\hline Цклеби & 136 & 136 & - \\
\hline часть Андоретского с/о, в т.ч. & 593 & 593 & - \\
\hline Андорети & 101 & 101 & - \\
\hline Биети & 97 & 97 & - \\
\hline Сакварети & 139 & 139 & - \\
\hline Телагина & 99 & 99 & - \\
\hline Тхинлара & 157 & 157 & - \\
\hline Бикарское с/о, в т.ч. & 847 & 847 & - \\
\hline Бикари & 208 & 208 & - \\
\hline Земо-Бикари & 141 & 141 & - \\
\hline Гомта & 72 & 72 & - \\
\hline Мериа & 185 & 185 & - \\
\hline Махиси II & 115 & 115 & - \\
\hline Харула & 126 & 126 & - \\
\hline часть Кливанского с/о, в т.ч. & 528 & 528 & - \\
\hline Накалакеви & 528 & 528 & - \\
\hline часть Лекаанского с/о, в т.ч. & 629 & 629 & - \\
\hline Аркинети & 71 & 71 & - \\
\hline Ахалиси & 126 & 126 & - \\
\hline Бендери & 256 & 256 & - \\
\hline Лекаани & 19 & 19 & - \\
\hline часть Меджврисхевского с/о, в т.ч. & 60 & - & 60 \\
\hline Громи & 60 & - & 60 \\
\hline
\end{tabular}

Как видно, этнический состав Меджудского ущелья в конце XIX в. характеризовался преобладанием осетин, которые составляли 90,2\% населения. Остальные 9,8\% населения ущелья составляли грузины. Б.А. Калоев отмечает, что Меджудское ущелье - один из последних по времени заселения осетинами регионов Южной Осетии (Калоев 2004: 117). Осетинское население Меджудского ущелья вместе с 
жителями ущелья Малой Лиахвы, Лехурского и Ксанского ущелий относится к этнографической группе чсанцев (ксанцев) (Блиев, Бзаров 2004: 167). Р.А. Топчишвили пишет, что верхняя часть Меджудского ущелья была заселена осетинами в начале XVIII века, тогда как массовая миграция осетинского населения из ущелий Большой и Малой Лиахвы в данный регион протекала в 1830-1880-х годах (Топчищвили 2009: 10-12). Интересно, что в 1886 г. село Гром являлось этнически грузинским, однако через несколько лет местные грузины переселяются ниже по течению Меджуды, в соседнее село Меджврисхеви, а Гром заселяется осетинами, став, таким образом, крайним южным осетинским селением на берегах Меджуды (Топчишвили 2009: 24).

По данным переписи 1886 г., немногочисленное грузинское население рассматриваемого ущелья, помимо села Гром, было сконцентрировано преимущественно в двух селах верхней зоны - Исролисхеви и Вилде. Первое из них являлось моноэтничным, второе - смешанным осетино-грузинским. Село Вилда делилось на две обособленные части: верхнюю с чисто грузинским населением и нижнюю со смешанным населением. Любопытно, что в указанной работе Р.А. Топчишвили пытается представить грузинское население верховий Меджуды, проживавшее здесь на момент посещения им ущелья в 1987 г., как «сохранившееся», «оставшееся на месте» (Топчишвили 2009: 26), то есть, пользуясь терминологическим аппаратом автора, - «доосетинское». На самом деле грузинское население сел Исролисхеви и Вилда в основном представлено потомками переселенцев из Мтиулети, осевших в верховьях Меджуды и ее притоков в конце XVIII века. Как ни странно, на это указывает в другой своей работе сам Р.А. Топчишвили (Топчишвили 2002: 14, 15).

Переселенцы-мтиулы, представители фамилий Гинтури, Генгиури, Елиаури, поселившись в Меджудском ущелье, долгое время живя в осетинском этническом окружении и на протяжении нескольких поколений вступая в браки с осетинками, впоследствии подверглись частичной ассимиляции. Р.А. Топчишвили описывает этнокультурное состояние одной из таких семей, по всей видимости, проживавшей в селе Вилда на закате советской эпохи, таким образом: «Смешанные осетино-грузинские браки тут обычное явление. Мы имели возможность гостить в одной из таких семей. Семья принадлежит к грузинской фамилии Генгиури. Глава семьи, 60 -летний мужчина, считает себя этническим грузином, говорит на прекрасном грузинском языке. Мать и жена главы семьи осетинки. Его пятеро детей имеют уже раздвоенное самосознание. Первое, что сразу же резало ухо, был осетинский акцент грузинской речи детей. Они обсуждали, к грузинской этнической группе принадлежат или к осетинской. Девушки склонялись к тому, что они осетинки, юноши также не особенно отстаивали свое грузинское происхождение» (Топчишвили 2009: 26).

Несмотря на то что в материалах переписи 1886 г. мтиулы (мтиулетины) фигурируют как отдельная этническая единица, за пределами коренного ареала расселения потомки выходцев из Мтиулети были записаны в основном грузинами. Это, в частности, относится к мтиулам Меджудского ущелья.

В период существования Грузинской Демократической Республики (19181921 гг.) в стране была проведена административная реформа, в соответствии с которой низовыми административно-территориальными единицами стали волости (теми). Югоосетинская элита сопротивлялась введению волостного деления в осетинских районах, видя в нем попытку Тифлиса окончательно снять с политической повестки вопрос о предоставлении Южной Осетии автономии (Маилян 2017: 103). 
Волостное деление в Южной Осетии просуществует до середины 1920-х гг. По итогам Всегрузинской сельскохозяйственной переписи 1923 г., количество жителей Меджудского ущелья составило 4129 чел., увеличившись за 37-летний межпереписной период на 216 чел. или на 5,5\%. Рубеж XIX-XX вв. в России был отмечен активным ростом населения при относительно скромных масштабах миграционной подвижности жителей. Однако в Меджудском ущелье в силу его периферийного экономико-географического положения, а также в связи с карательной операцией, проведенной грузинскими властями в Южной Осетии в 1920 г. и вызвавшей массовый, преимущественно временный, исход части осетинского населения в Северную Осетию, миграционный отток в обозначенный период времени достиг таких масштабов, что высокий естественный прирост едва успевал его компенсировать. Из общей численности населения ущелья в пределах Андоретской волости в 1923 г. проживали 3617 чел., а в пределах Лехурской волости, куда входила верхняя часть Меджудского ущелья, -512 чел.

Таблица 2

Этнический состав населенных пунктов Меджудского ущелья, 1923 г.

(Итоги 1925: 163, 167)

\begin{tabular}{|c|c|c|c|}
\hline & всего жителей & осетины & грузины \\
\hline Меджудское ущелье, в т.ч. & 4129 & 3860 & 269 \\
\hline часть Андоретской волости, в т.ч. & 3617 & 3481 & 136 \\
\hline Андорети & 154 & 154 & - \\
\hline Аркинарети & 103 & 103 & - \\
\hline Ахалиса & 138 & 138 & - \\
\hline Биети & 96 & 96 & - \\
\hline Бендери & 301 & 301 & - \\
\hline Земо-Бикари & 152 & 152 & - \\
\hline Квемо-Бикари & 206 & 206 & - \\
\hline Земо-Горети & 300 & 300 & - \\
\hline Квемо-Горети & 153 & 153 & - \\
\hline Громи & 262 & 254 & 8 \\
\hline Вилда & 263 & 142 & 121 \\
\hline Телагина & 116 & 116 & - \\
\hline Иалбузи & 24 & 24 & \\
\hline Иврети & 152 & 152 & - \\
\hline Махиси & 276 & 276 & - \\
\hline
\end{tabular}


Таблица 2 (продолжение)

\begin{tabular}{|c|c|c|c|}
\hline & всего жителей & осетины & грузины \\
\hline Мериа & 43 & 43 & - \\
\hline Накалакеви & 115 & 115 & - \\
\hline Ниши & 53 & 53 & - \\
\hline Саквирети & 288 & 281 & 7 \\
\hline Сакодахчини & 49 & 49 & - \\
\hline Тба & 46 & 46 & - \\
\hline Харули & 75 & 75 & - \\
\hline Хсаргони & 156 & 156 & - \\
\hline Чалисубани & 96 & 96 & - \\
\hline часть Лехурской волости, в т.ч. & 512 & 379 & 133 \\
\hline Асатура & 119 & 119 & - \\
\hline Ардиси & 144 & 144 & - \\
\hline Двалианткари & 69 & 69 & - \\
\hline Исролисхеви & 145 & 12 & 133 \\
\hline Олопта & 35 & 35 & - \\
\hline
\end{tabular}

Динамика этнодемографической ситуации в ущелье в межпереписной период 1886-1923 гг. характеризуется увеличением доли осетинского населения (с 90,2\% до 93,5\%) при параллельном сокращении удельного веса грузин (с 9,8\% до 6,5\%). Сокращение численности и доли грузинского населения связано с переселением жителей села Гром в соседнее Меджврисхеви, а также с оттоком грузин из Исролисхеви и Вилды в том же направлении. Рост доли осетинского населения вызван не только сокращением численности грузин, но и продолжающейся миграцией осетин из ущелья Малой Лиахвы. Так, в обозначенный период в Меджудском ущелье возникают новые осетинские села: Горет, Иврет и другие. Индикатором появления в ущелье смешанных грузино-осетинских браков на рубеже XIX-XX вв. служит фиксация присутствия осетин в некогда абсолютно моноэтничном грузинском селе Исролисхеви. В 1923 г. осетины составляют 8,3\% населения последнего. Очевидно, что они были представлены преимущественно женами местных грузин, происходившими из соседних осетинских селений.

Первая Всесоюзная перепись населения 1926 г. была проведена спустя 3 года после сельскохозяйственной переписи Грузии, что позволяет нам, с одной стороны, проанализировать изменения, произошедшие за короткий промежуток времени на раннем этапе советского строительства, с другой - обратить внимание на возможные изъяны переписи 1923 г., качество проведения которой, очевидно, уступало переписи 1926 г. Согласно данным переписи 1926 г., численность населения Меджудского ущелья со- 
ставляла 4220 человек, из которых 2272 проживали в Бикарском сельсовете, полностью располагавшемся в пределах ущелья, 1576 - на территории Громского сельсовета и 43 - в селе Олопта, относившемся к Захорскому сельсовету. Таким образом, за 3 года численность населения ущелья увеличилась на 91 человека или на 2,2\%, что вполне соотносится с общими демографическими тенденциями того периода.

Таблица 3

Этнический состав населенных пунктов Меджудского ущелья, 1926 г. (Административно-территориальное 1930: 183, 187, 188, 190)

\begin{tabular}{|c|c|c|c|c|}
\hline & всего жителей & осетины & грузины & остальные \\
\hline Меджудское ущелье, в т.ч. & 4220 & 3868 & 332 & 20 \\
\hline часть Захорского с/с, в т.ч. & 43 & 43 & - & - \\
\hline Олопта & 43 & 43 & - & - \\
\hline Бикарский с/с, в т.ч. & 2601 & 2272 & 324 & 5 \\
\hline Ардиси & 127 & 127 & - & - \\
\hline Асатури & 87 & 87 & - & - \\
\hline Ахалиса & 105 & 105 & - & - \\
\hline Бендери & 320 & 320 & - & - \\
\hline Бетат-Кау & 21 & 21 & - & - \\
\hline Земо-Бикари & 216 & 216 & - & - \\
\hline Квемо-Бикари & 235 & 235 & - & - \\
\hline Двалианткари & 82 & - & 82 & - \\
\hline Земо-Вилда & 62 & - & 62 & - \\
\hline Квемо-Вилда & 268 & 158 & 105 & 5 \\
\hline Иалбузи & 38 & 38 & - & - \\
\hline Исролисхеви & 167 & 30 & 137 & - \\
\hline Земо-Махиси & 329 & 329 & - & - \\
\hline Квемо-Махиси & 58 & 58 & - & - \\
\hline Мериа & 24 & 24 & - & - \\
\hline Ниши & 31 & 31 & - & - \\
\hline Сау-Кодахджини & 70 & 70 & - & - \\
\hline Тба & 42 & 42 & - & - \\
\hline Чалисубани & 96 & 96 & - & - \\
\hline
\end{tabular}


Таблица 3 (продолжение)

\begin{tabular}{|c|c|c|c|c|}
\hline & всего жителей & осетины & грузины & остальные \\
\hline Чинарети & 103 & 103 & - & - \\
\hline Харули & 110 & 110 & - & - \\
\hline часть Громского с/с, в т.ч. & 1576 & 1553 & 8 & 15 \\
\hline Андорети & 136 & 136 & - & - \\
\hline Ахсарджини & 146 & 146 & - & - \\
\hline Биети & 74 & 74 & - & - \\
\hline Земо-Горети & 251 & 251 & - & - \\
\hline Квемо-Горети & 110 & 110 & - & - \\
\hline Телагина & 78 & 78 & - & - \\
\hline Иврети & 111 & 111 & - & - \\
\hline Накалакеви & 107 & 107 & - & - \\
\hline Саквирети & 237 & 223 & 8 & 6 \\
\hline Диди Громи & 273 & 264 & - & 9 \\
\hline Патара Громи & 53 & 53 & - & - \\
\hline
\end{tabular}

Непродолжительный межпереписной период 1923-1926 гг. ознаменовался довольно существенными трансформациями этнодемографической структуры населения Меджудского ущелья. Доля осетинского населения снизилась с 93,5\% до 91,7\%, грузинского - повысилась с 6,5\% до 7,9\%. Помимо этого, перепись 1926 г. впервые зафиксировала проживание в ущелье представителей прочих этносов, суммарный удельный вес которых составил $0,5 \%$.

Поселенные итоги переписи 1926 г. свидетельствуют о том, что рост численности и доли грузин объясняется изменением этнического состава населения Двалианткари. По итогам переписи 1923 г., Двалианткари значится как моноэтничное осетинское село, а по переписи 1926 г. - как полностью грузинское. Представляется вполне очевидным, что если бы в данном селе в обозначенный промежуток времени произошла полная смена населения (например, в результате миграций), то этот факт был бы задокументирован. Забегая вперед, отметим, что по данным всех последующих советских переписей Двалианткари вновь будет фигурировать как этнически грузинское село. Подобная ситуация, на наш взгляд, может объясняться или ошибкой в ходе проведения одной из двух переписей (1923 либо 1926 гг.), или неоднозначностью этнокультурной самоидентификации жителей Двалианткари. Название села представляет собой отфамильный антропокомоним и свидетельствует о том, что оно изначально являлось местом преимущественного проживания представителей фамилии Двали[швили]. Факт их проживания в селе в конце XIX в. подтверждается докладом ксанского пристава князя К.Р. Шаликова тифлисскому уездному начальнику от 7 августа 1891 г. (Цховребов 1961: III, 425). Как и представители большинства других 
современных осетинских и грузинских фамилий Меджудского ущелья, носители фамилии Двалишвили переселились сюда не ранее XVIII в. (вероятно, в конце XIX в., поскольку перепись 1886 г. не фиксирует села Двалианткари). По всей видимости, первые поселенцы, основавшие Двалианткари, были выходцами из картвельской этнической среды. 3.Д. Цховребова пишет, что топоним Двалианткари образован от грузинской фамилии Двалишвили (Цховребова 1979: 154). Таким образом, есть основания полагать, что ошибочными могут быть данные переписи 1923 г., а не 1926 г.

Итоги переписи 1926 г. демонстрируют продолжающийся стремительный рост числа смешанных грузино-осетинских браков в Исролисхеви: доля осетин в селе за 3 года выросла с 8,3\% до 18,0\%. Вместе с тем верхняя (грузинская) часть села Вилда продолжает оставаться полностью этнически гомогенной.

Последующие советские переписи, подробные данные которых имеются у нас в наличии (1959 и 1989 гг.), не предоставляют точной численности представителей основных этносов в каждом сельском населенном пункте. Материалы переписи 1959 г. показывают общую численность населения всех населенных пунктов и численно преобладающую национальность в каждом из них. Данные переписи 1989 г., помимо вышеуказанных сведений, отображают процентное соотношение основных этносов в полиэтничных селах.

По итогам переписи 1959 г., численность населения Меджудского ущелья составляла 2576 чел., из которых 1567 проживали в пределах Бикарского сельсовета, 972 - в границах Громского сельсовета и 37 - в селе Накалакеви, в тот период относившемся к Ксуисскому сельсовету. Активная депопуляция сельского населения горных, труднодоступных, имеющих периферийное экономико-географическое положение территорий Южной Осетии, к числу которых относится и Меджудское ущелье, началась значительно раньше, чем в большинстве других регионов СССР. В межпереписной период 1926-1959 гг. число жителей Меджудского ущелья сократилось на 1644 чел. или на 39,0\%.

Таблица 4

Этнический состав населенных пунктов Меджудского ущелья, 1959 г. (Российский государственный архив экономики)

\begin{tabular}{l|c|c}
\hline & $\begin{array}{c}\text { численность } \\
\text { населения }\end{array}$ & $\begin{array}{c}\text { преобладающая } \\
\text { национальность }\end{array}$ \\
\hline Меджудское ущелье, в т.ч. & 2576 & \\
\hdashline часть Бикарского с/с, в т.ч. & 1567 & 96 \\
\hline Аркнарет & 54 & осетины \\
\hline Савкодаджин & 56 & осетины \\
\hline Ахалиса & 277 & осетины \\
\hline Бендери & 190 & осетины \\
\hline Средний Махиси & 61 & осетины \\
\hline Нижний Махиси & & осетины \\
\hline
\end{tabular}


Таблица 4 (продолжение)

\begin{tabular}{|c|c|c|}
\hline & $\begin{array}{c}\text { численность } \\
\text { населения }\end{array}$ & $\begin{array}{l}\text { преобладающая } \\
\text { национальность }\end{array}$ \\
\hline Верхний Махиси & 25 & осетины \\
\hline Верхний Бикари & 74 & осетины \\
\hline Нижний Бикари & 155 & осетины \\
\hline Чалисубани & 85 & осетины \\
\hline Тба & 9 & осетины \\
\hline Нижняя Вильда & 166 & осетины \\
\hline Верхняя Вильда & 38 & осетины \\
\hline Двалианткари & 67 & грузины \\
\hline Ардиси & 118 & осетины \\
\hline Исролисхеви & 44 & осетины \\
\hline Асатури & 37 & осетины \\
\hline Нижний Цклеби & 15 & осетины \\
\hline часть Ксуисского с/с, в т.ч. & 37 & \\
\hline Накалакеви & 37 & осетины \\
\hline часть Громского с/с, в т.ч. & 972 & \\
\hline Большой Громи & 375 & осетины \\
\hline Малый Громи & 28 & осетины \\
\hline Саквирети & 41 & осетины \\
\hline Ахсаргин & 63 & осетины \\
\hline Андорет & 104 & осетины \\
\hline Иврети & 73 & осетины \\
\hline Биети & 54 & осетины \\
\hline Телагин & 67 & осетины \\
\hline Нижний Горети & 52 & осетины \\
\hline Верхний Горети & 115 & осетины \\
\hline
\end{tabular}

В период с 1926 г. по 1959 г. депопуляция затронула как осетинское, так и грузинское население Меджудского ущелья. Не располагая точными данными по абсолютной численности осетин и грузин в рассматриваемом регионе в 1959 г., мы все же можем предположить, что к началу второй половины XX века процесс этнической гомогенизации ущелья продолжался. Так, по данным переписи 1959 г., в регионе осталось лишь 
одно село с преобладанием грузинского населения - Двалианткари. Продолжающаяся практика заключения смешанных браков привела к тому, что в селах Вилда и Исролисхеви абсолютное большинство жителей уже имело осетинскую идентичность, что связано не только с ростом доли невесток из соседних осетинских селений, но и с трансформацией этнической идентичности потомства от смешанных грузино-осетинских брачных союзов во втором и последующих поколениях. Один подобный пример, зафиксированный Р. Топчишвили в конце советской эпохи, был представлен выше.

По данным последней советской переписи 1989 г., население Меджудского ущелья составляло 913 чел. Бо́льшая часть жителей (501 чел.) проживала в границах Бикарского сельсовета, полностью находившегося в пределах Меджудского ущелья, остальные 412 чел. - в границах Громского сельсовета. В 1960-1980-х гг. депопуляция населения рассматриваемого региона усилилась, чему теперь способствовала не только периферийность его экономико-географического положения, но и общий вектор миграционных процессов в Советском Союзе, характеризовавшийся резким усилением оттока сельского населения в города. За 30 лет, прошедших с момента проведения переписи 1959 г., число жителей Меджудского ущелья сократилось на 1663 чел. или на $64,6 \%$.

Таблица 5

Этнический состав населенных пунктов Меджудского ущелья, 1989 г. (Населенные пункты 1991: 71-74)

\begin{tabular}{|c|c|c|}
\hline & численность населения & $\begin{array}{l}\text { преобладающая } \\
\text { национальность }\end{array}$ \\
\hline Меджудское ущелье, в т.ч. & 913 & \\
\hline Бикарский с/с, в т.ч. & 501 & \\
\hline Квемо-Бикари & 101 & осетины \\
\hline Земо-Бикари & 14 & осетины \\
\hline Квемо-Махиси & 39 & осетины \\
\hline Шуа-Махиси & 105 & осетины \\
\hline Аркинарети & 39 & осетины \\
\hline Бендери & 45 & осетины \\
\hline Ахалиса & 27 & осетины \\
\hline Чалисубани & 6 & осетины \\
\hline Земо-Вилда & 60 & осетины - 70\%, грузины - 30\% \\
\hline Двалианткари & 19 & грузины \\
\hline Исролисхеви & 8 & грузины \\
\hline Ардиси & 38 & осетины \\
\hline часть Громского с/с, в т.ч. & 412 & \\
\hline
\end{tabular}


Таблица 5 (продолжение)

\begin{tabular}{l|c|c}
\hline & численность населения & $\begin{array}{c}\text { преобладающая } \\
\text { национальность }\end{array}$ \\
\hline Диди-Громи & 185 & осетины \\
\hline Саквирети & 2 & осетины \\
\hdashline Андорети & 68 & осетины \\
Ниши & 28 & осетины \\
\hline Биети & 19 & осетины \\
\hdashline Иврети & 15 & осетины \\
\hline Телагина & 24 & осетины \\
\hline Квемо-Горети & 37 & осетины \\
\hline Земо-Горети & 34 & осетины \\
\hline
\end{tabular}

Период между переписями 1959 и 1989 гг. был ознаменован резкой депопуляцией осетинского населения региона. К 1989 г. более-менее крупными населенными пунктами ущелья остаются некоторые села на берегах Меджуды (Андорет, Бикар, Гром, Махис), тогда как селения по притокам этой реки, за редким исключением, обезлюдели или практически обезлюдели. Исролисхеви вновь становится этнически грузинским селом, однако, учитывая общую численность его населения (8 чел.), подобные изменения вряд ли сто́ит принимать во внимание. Процентное соотношение осетин и грузин в Верхней Вилде (70 к 30), еще в середине 1920 -х годов населенной исключительно грузинами, является наглядным статистическим подтверждением трансформации этнической идентичности под влиянием полувековой практики заключения смешанных браков.

Процессы депопуляции во второй половине XX в. происходили и в большинстве других сельских районов автономной области. Они были вызваны началом активной урбанизации южных осетин. Основными урбанизационными центрами для меджудских осетин, помимо Цхинвала, стали грузинские города Гори и Тбилиси, а также Владикавказ и другие города РСФСР. Р.А. Топчишвили отмечает, что количество грузин в Меджудском ущелье «за годы советской власти сильно убавилось» (Tonчишвили 2009: 26). Однако в еще большей степени депопуляция затронула самих осетин, на протяжении всего рассматриваемого периода составлявших подавляющее большинство населения ущелья. Численность сельского осетинского населения Южной Осетии начиная с 1940-х гг. неуклонно сокращалась вследствие урбанизации, тогда как для грузин в сельской местности автономной области в советский период была характерна скорее стагнация численности, являвшаяся следствием меньшего миграционного оттока. В Цхинвальском районе ${ }^{1}$ Южной Осетии, в пределах которого расположено Меджудское ущелье, эти процессы вызывали неуклонное сокращение доли осетинского населения при параллельном увеличении удельного веса грузин (см. табл. 6).

${ }^{1}$ Город Цхинвал не входил в состав Цхинвальского района. 
Таблица 6

Динамика этнической структуры населения Цхинвальского района ЮгоОсетинской АО, 1939-1989 г. (13, 14, 15, 16, 17 Населенные 1991, Российский государственный архив экономики. Ф. 1562. Оп. 336, 338)

\begin{tabular}{|c|c|c|c|c|c|}
\hline & 1939 г. & 1959 г. & 1970 г. & 1979 г. & 1989 г. \\
\hline все население & 30693 & 27295 & 26653 & 25405 & 23514 \\
\hline осетины & $\begin{array}{c}20280 \\
(66,1 \%)\end{array}$ & $\begin{array}{c}16924 \\
(62,0 \%)\end{array}$ & $\begin{array}{c}15567 \\
(58,4 \%)\end{array}$ & $\begin{array}{c}14157 \\
(55,7 \%)\end{array}$ & $\begin{array}{c}12370 \\
(52,6 \%)\end{array}$ \\
\hline грузины & $\begin{array}{c}10036 \\
(32,7 \%)\end{array}$ & $\begin{array}{c}9930 \\
(36,4 \%)\end{array}$ & $\begin{array}{c}10752 \\
(40,3 \%)\end{array}$ & $\begin{array}{c}11008 \\
(43,3 \%)\end{array}$ & $\begin{array}{c}10926 \\
(46,5 \%)\end{array}$ \\
\hline русские & $\begin{array}{c}196 \\
(0,6 \%)\end{array}$ & $\begin{array}{c}252 \\
(0,9 \%)\end{array}$ & $\begin{array}{c}117 \\
(0,4 \%)\end{array}$ & $\begin{array}{c}106 \\
(0,4 \%)\end{array}$ & $\begin{array}{c}96 \\
(0,4 \%)\end{array}$ \\
\hline остальные & $\begin{array}{c}181 \\
(0,6 \%)\end{array}$ & $\begin{array}{c}189 \\
(0,7 \%)\end{array}$ & $\begin{array}{c}217 \\
(0,8 \%)\end{array}$ & $\begin{array}{c}134 \\
(0,5 \%)\end{array}$ & $\begin{array}{c}122 \\
(0,5 \%)\end{array}$ \\
\hline
\end{tabular}

Общее ухудшение экономической ситуации, связанное со сложным комплексом проблем эпохи перестройки, распад Советского Союза, грузино-югоосетинская война 1991-1992 гг. и последовавшая за ней политическая и социально-экономическая неопределенность в условиях неурегулированности конфликта предопределили дальнейшую интенсификацию начавшихся во второй половине XX века этнодемографических процессов в Меджудском ущелье. По данным последней переписи населения Южной Осетии, проведенной в 2015 г., число жителей рассматриваемой территории сократилось до 485 чел. В настоящее время Меджудское ущелье административно разделено на две сельские администрации - Бикарскую и Громскую. В пределах Бикарской сельской администрации, охватывающей верхнюю половину ущелья, в 2015 г. проживали 175 чел., в Громской (нижняя часть ущелья) - 310 чел. Данные переписи 2015 г. не предоставляют сведений об этническом составе населения отдельных сел, однако в целом в Цхинвальском районе было учтено 309 жителей грузинской национальности (Итоги 2016: 102), абсолютное большинство которых, очевидно, проживало за пределами Меджудского ущелья. Общая численность населения сел Исролисхеви, Туалта (Двалианткари) и Вилда, в пределах которых проживала основная масса грузин Меджудского ущелья, составляла 25 чел. Абсолютное большинство населения этих сел, судя по данным переписи 1989 г., уже тогда составляли осетины. Таким образом, есть все основания полагать, что этническая гомогенизация ущелья к настоящему времени практически завершилась. Отдельные жители грузинской национальности, по-прежнему проживающие в ущелье, представлены преимущественно мужчинами старшего поколения, происходящими из этнически смешанных семей. В культурно-бытовом и языковом отношении они фактически составляют единое целое с окружающим осетинским населением.

Численность населения Меджудского ущелья с 1940-х гг. постоянно сокращалась. Главными причинами депопуляции были периферийность экономико-географического положения ущелья, его транспортная полуизоляция от административного центра Юго-Осетинской Автономной области, общие демографические тенденции второй половины ХХ столетия, грузино-осетинская война 1991-1992 гг. и последующая сложная политическая и экономическая ситуация в регионе. Этнический состав 
населения Меджудского ущелья на протяжении всего рассматриваемого периода характеризовался абсолютным преобладанием осетин, которые никогда не составляли менее $90 \%$ от общего числа жителей. Доля осетинского населения в ущелье постоянно нарастала, что было связано в первую очередь с ассимиляцией местного грузинского населения под влиянием практики заключения смешанных браков, а в отдельные периоды (в конце XIX века и после распада СССР) - и с миграцией грузин за пределы ущелья, на территорию Грузии.

Таблица 7

Численность населения сел Меджудского ущелья, 2015 г. (Итоги 2016)

\begin{tabular}{|c|c|}
\hline & численность населения \\
\hline Меджудское ущелье, в т.ч. & 485 \\
\hline Бикарская с/а, в т.ч. & 175 \\
\hline Махис & 75 \\
\hline Бикар & 49 \\
\hline Арджынараг & 8 \\
\hline Бендер & 5 \\
\hline Чалисубан & 6 \\
\hline Вилда & 21 \\
\hline Туалта & 2 \\
\hline Ардис & 7 \\
\hline Исролисхев & 2 \\
\hline Громская с/а, в т.ч. & 310 \\
\hline Гром & 231 \\
\hline Андорат & 16 \\
\hline Ниши & 11 \\
\hline Верхний Горат & 20 \\
\hline Нижний Горат & 11 \\
\hline Иврет & 15 \\
\hline Таладжын & 6 \\
\hline
\end{tabular}

В настоящее время в пределах Меджудского ущелья не наблюдается никаких предпосылок к положительной демографической динамике. Бо́льшая часть жителей ущелья представлена людьми старших возрастных когорт. Несмотря на то что ущелье с 2014 г. получило качественное транспортное сообщение со столицей Южной Осетии и стало транзитным регионом во внутриреспубликанском масштабе, миграционный 
отток не прекратился. В селе Гром, на левом берегу Меджуды, расположена российская военная база, однако ее контингент не был охвачен переписью населения 2015 г.

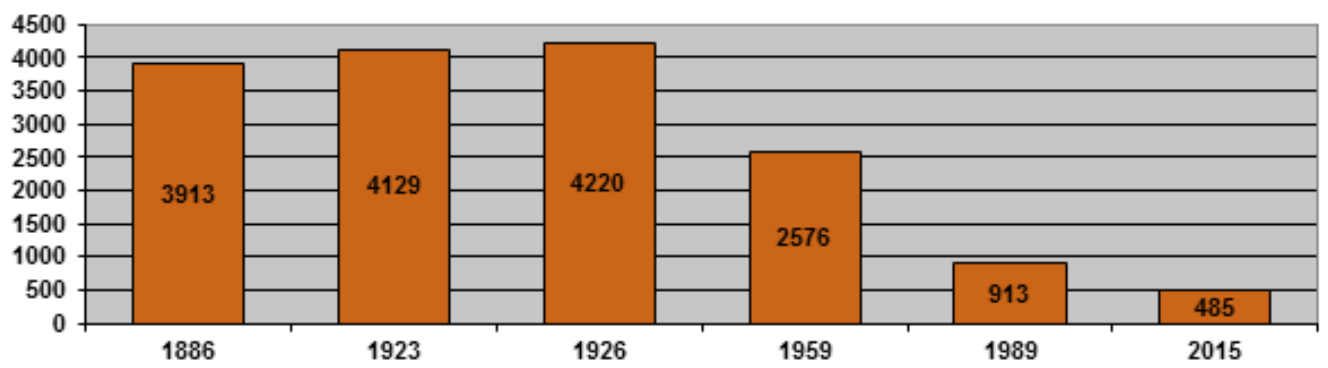

Рис. 2. Динамика численности населения Меджудского ущелья (1886-2015 г2.).

\section{Источники и материалы}

Административно-территориальное 1930 - Административно-территориальное деление ССР Грузии. Тифлис, 1930. 236 с.

Итоги Всегрузинской 1925 - Итоги Всегрузинской сельскохозяйственной переписи 1923 года. Вып. 1. Ч. 2. Тифлис, 1925. 301 с.

Итоги всеобщей переписи 2016 - Итоги всеобщей переписи населения Республики Южная Осетия. Цхинвал, 2016. 452 с.

Кавказский календарь 1916 - Кавказский календарь на 1917 год. Тифлис: Типография Козловского, 1916. 1609 с.

Населенные пункты 1991 - Населенные пункты и население Грузии (по данным Всесоюзной переписи 1989 года). Статистический справочник. Тбилиси, 1991. 156 с.

РГАЭ - Российский государственный архив экономики. Ф. 1562. Оп. 336. Д. 3799.

РГАЭ. Ф. 1562. Оп. 336. Д. 999 - Российский государственный архив экономики. Ф. 1562. Оп. 336. Д. 999.

РГАЭ. Ф. 1562. Оп. 336. Д. 999 - Российский государственный архив экономики. Ф. 1562. Оп. 338. Ч. 1. Д. 572.

РГАЭ. Ф. 1562. Оп. 338. Ч. 2. Д. 333 - Российский государственный архив экономики. Ф. 1562. Оп. 338. Ч. 2. Д. 333.

РГАЭ. Ф. 1562. Оп. 338. Ч. 3. Д. 481 - Российский государственный архив экономики. Ф. 1562. Оп. 338. Ч. 3. Д. 481.

Свод статистических данных 1893 - Свод статистических данных о населении Закавказского края, извлеченных из посемейных списков 1886 г. Тифлис, 1893.974 с.

\section{Научная литература}

Блиев М.М., Бзаров Р.С. История Осетии с древнейших времен до конца ХІХ в. Владикавказ: Ир, 2000. $351 \mathrm{c.}$

Калоев Б.А. Осетины: Историко-этнографическое исследование. Москва: Наука, 2004. 504 с.

Маилян Б.В. Земля и люди: о некоторых аспектах вопроса политической институционализации южных осетин в 1917-1920 годах // Историческое пространство: проблемы истории стран СНГ / сост. А.В. Шубин, М.С. Яковлев, глав. ред. А.О. Чубарьян. Москва: Наука, 2017. C. 97-114.

Топчишвили Р.А. Осетины в Грузии: миф и реальность. Тбилиси, 2009. 257 с.

Топчишвили Р.А. Из исторической демографии Грузии (этноисторические проблемы миграций горского населения Шида-Картли). Тбилиси: Мематиане, 2002. 90 с. (на груз. яз.). 
Цховребов И.Н. (отв. ред.) История Юго-Осетии в документах и материалах (1864-1900 гг.). Цхинвали: Госиздат Юго-Осетии, 1961. 270 с.

Цховребова 3.Д. Топонимия Южной Осетии в письменных источниках. Тбилиси: Мецниереба, $1979.184 \mathrm{c.}$

\section{References}

Bliev, M.M., and R.S. Bzarov. 2000. Istoriya Osetii s drevneishikh vremen do kontsa XIX v. [The history of Ossetia from ancient times to the end of the $19^{\text {th }}$ century]. Vladikavkaz: Ir Publ.

Kaloev, B.A. 2004. Osetiny: Istoriko-etnograficheskoe issledovanie [The Ossetians: Historical and Ethnographic Survey]. Moscow: Nauka Publ.

Mailian, B.V. 2017. Zemlya i liudi: o nekotorykh aspektakh voprosa politicheskoi institutsionalizatsii yuzhnykh osetin v 1917-1920 godakh [Land and people: about some aspects of the issue of political institutionalization of South Ossetians in 1917-1920]. In Istoricheskoe prostranstvo: problemy istorii stran SNG [Historical space: problems of the history of the CIS countries], edited by A.V. Shubin, M.S. Yakovlev, A.O. Chubarian, 97-114. Moscow: Nauka.

Topchishvili, R.A. 2009. Osetiny v Gruzii: mif i real'nost'[Ossetians in Georgia: Myth and Reality]. Tbilisi.

Topchishvili, R.A. 2002. Iz istoricheskoi demografii Gruzii (etnoistoricheskie problemy migratsii gorskogo naseleniya Shida-Kartli) [From the historical demography of Georgia (ethno-historical problems of migration of the mountain population of Shida-Kartli)]. Tbilisi: Mematiane.

Tskhovrebov, I.N (ed.). 1961. Istoriya Yugo-Osetii v dokumentakh i materialakh (1864-1900 gg.) [The history of South Ossetia in documents and materials (1864-1900)]. Tskhinvali: Gosizdat Yugo-Osetii.

Tskhovrebova, Z.D. 1979. Toponimiya Yuzhnoi Osetii v pis'mennykh istochnikakh [Toponymy of South Ossetia in written sources]. Tbilisi: Metsniereba.

\section{Bagapsh, Nuri $V$.}

\section{Dynamics of the Ethno-Demographic Situation in the Mejuda Gorge of South Ossetia (1886-2015)}

The work examines the dynamics of the demographic situation and the ethnic composition of the population in the Mejuda gorge of South Ossetia in the period from 1886 to 2015. Throughout this period Mejuda gorge had a peripheral economic-geographical position. In Soviet times, the gorge did not have direct transport connection with other parts of South Ossetia and was economically focused mainly on the Gori district of Georgia. This fact greatly complicated the humanitarian situation in the microregion in the politicalgeographical realities that changed after the collapse of the USSR. These reasons have determined the steady depopulation of the Mejuda gorge since the 1940s. The rate of decline in the number of inhabitants has particularly accelerated since the early 1990s.

Key words: Mejuda gorge, South Ossetia, ethnic demography of the Caucasus, migration in the South Caucasus, Ossetians, Mtiulians 